\title{
Conducting tensometric monitoring of the technical and stress-strain state of underground facilities
}

\author{
Alexey Yurgaytis ${ }^{1, *}$, Dmitriy Topchiy ${ }^{1}$ and Vitaly Chernigov ${ }^{2}$ \\ ${ }^{1}$ Moscow State University of Civil Engineering, 129337, 26, Yaroslavskoye Shosse, Moscow, Russia \\ ${ }^{2}$ LLC "Scientific Research Institute of Design, Technology and Expertise of Construction", 127576, \\ 1A, Novgorodskaya st., Moscow, Russia
}

\begin{abstract}
The authors describe the experience of carrying out a scientific and technical research study as part of scientific and technical support at the construction and design stages of large-scale construction projects in the city of Moscow (including unique ones). Analytical data are presented as a result of studying the stressed-deformed state of a pile foundation with step-by-step application of load in the course of implementing civil construction projects.
\end{abstract}

\section{Introduction}

When designing buildings and structures based on the current regulatory framework (including [1]), the developers of design documentation take into account a wide range of safety factors in order to ensure the regulator compliant safety and reliability levels specified for a given object (see. Table 1).

Table 1. Safety factors according to the SP 20.13330.2011 Loads and Effects.

\begin{tabular}{|l|l|c|}
\hline No. & $\begin{array}{c}\text { Safety factor name as per Russian state standard SP } \\
20.13330 .2011 \text { Loads and Effects }\end{array}$ & $\begin{array}{c}\text { Safety factor designation as per } \\
\text { SP 20.13330.2011 Loads and } \\
\text { Effects }\end{array}$ \\
\hline 1. & Partial safety for materials & $\gamma_{m}$ \\
\hline 2. & Partial safety for loads & $\gamma$ \\
\hline 3. & Partial safety for work conditions & $\gamma_{c}$ \\
\hline 4. & Partial safety the facility level of responsibility & $K_{n}$ \\
\hline 5. & Partial safety for intended purpose reliability & $\gamma_{n}$ \\
\hline 6. & Partial safety for ground & $\gamma_{g}$ \\
\hline
\end{tabular}

Using the abovementioned factors is one of the basic features of the calculation of buildings and structures using the two limiting conditions method (see. Table. 2). This method is widely used today for design calculations (including verification calculations). However, the existing legal and technical basis clearly defines the procedure for definition

*Corresponding author:aljurgaitis@gmail.com 
of the cross sections dimensions of bearing elements of the buildings frame and the foundations, concrete reinforcement, location of necessary reinforcing elements (eg, visible and hidden capitals, strengthening of the columns punching areas, etc.) based on a strength condition, rigidity and stability. This results in the fact that it is now always possible to achieve the optimum components sizes. First of all, it relates to the economic feasibility (economy) issues as well as labor and material consumption in the design and construction of unique objects (see. Table. 3, [3]). Obviously, the regulatory and technical basis governing the construction design and production is not able to include all possible features of buildings and structures, as well as the unique features of the building conditions used in practice, despite frequent updates. It is impossible to achieve a maximum classification of objects by type in the conditions where development of creative engineering leads to a creation of unique objects, each having its own specific features (including architecture, structural elements, engineering systems, location, etc.).

Table 2. Calculation of building structures on modern methods of two limit states.

\begin{tabular}{|l|l|l|}
\hline No. & Limit state & \multicolumn{1}{c|}{ Calculation description } \\
\hline 1 & $\begin{array}{l}\text { The first } \\
\text { limit state }\end{array}$ & $\begin{array}{l}\text { Determining the bearing capacity of the structure component (strength and resistance } \\
\text { for compressed members) }\end{array}$ \\
\hline 2 & $\begin{array}{l}\text { The second } \\
\text { limit state }\end{array}$ & $\begin{array}{l}\text { Determining the maximum admissible deformation based on the smooth functioning } \\
\text { condition in accordance with a predetermined purpose and physiological and } \\
\text { aesthetic requirements }\end{array}$ \\
\hline
\end{tabular}

Table 3. Signs of especially dangerous, technically complex and unique buildings and structures in accordance with an applicable regulatory and technical base.

\begin{tabular}{|c|c|c|c|}
\hline No. & Facility category & Facilities included in the class & Reference \\
\hline 1. & $\begin{array}{l}\text { Especially } \\
\text { dangerous }\end{array}$ & \multirow[b]{2}{*}{$\begin{array}{l}\text { 1. Nuclear facilities, } \\
\text { waterworks, } \\
\text { 2. communication facilities, } \\
\text { 3. power lines and other electric grid } \\
\text { facilities with voltage of } 330 \mathrm{kV} \text { or } \\
\text { more, } \\
\text { 4. space facilities, } \\
\text { 5. air transport facilities, } \\
\text { 6. capital construction facilities of } 7 . \\
\text { common use railways infrastructure, } \\
\text { 8. subways, } \\
\text { 9. port waterworks, } \\
\text { 10. thermal power plants, } \\
\text { 11. air cableways, } \\
\text { 12. other hazardous industrial } \\
\text { facilities. }\end{array}$} & \multirow{3}{*}{$\begin{array}{l}\text { Town Planning Code } \\
\text { of the Russian } \\
\text { Federation } \\
\text { Chapter } 6 \text {. } \\
\text { Architectural and } \\
\text { structural design, } \\
\text { construction, } \\
\text { reconstruction of } \\
\text { capital construction } \\
\text { (articles } 47 \text { to 55) } \\
\text { Article } 48.1 \text {. Especially } \\
\text { dangerous, technically } \\
\text { complex and unique } \\
\text { objects }\end{array}$} \\
\hline 2. & $\begin{array}{l}\text { Technically } \\
\text { complex }\end{array}$ & & \\
\hline 3. & Unique facilities & $\begin{array}{l}\text { 1. height over } 100 \text { meters; } \\
\text { 2. passages over } 100 \text { meters; } \\
\text { 3. presence of a console with a } \\
\text { length above } 20 \text { meters; } \\
\text { 4. burying an underground part } \\
\text { (partially or fully) more than } 15 \\
\text { meters below the land planning } \\
\text { level. }\end{array}$ & \\
\hline
\end{tabular}

Currently, the design of such unique facilities is performed based on a similar experience and using reliable solutions to the unique facilities construction that may be compared and correlated in terms of their the technical and structural characteristics. The similarity theory is not always able to provide optimized production solutions. The design 
companies do not always perform analysis properly, so the investor of a construction has to bear additional costs arising from redundancy in the designing of buildings and structures.

Let us show the desire to optimize the sections of bearing components and consequently to reduce the consumption of materials and the estimated cost of construction on an example of authors' practical experience in monitoring of the actual stress-strain state of the foundation piles of the large unique facility in the city of Moscow. The purpose of this monitoring is to measure the actual stress tensor and its correlation with the calculated values obtained in the course of designing by the General designer company based on similar objects (see Table 4.).

Table 4. Purposes of the stress-strain state monitoring of concrete pile foundation of a unique object.

\begin{tabular}{|l|l|l|}
\hline No. & \multicolumn{1}{|c|}{$\begin{array}{c}\text { Task } \\
\text { category }\end{array}$} & \multicolumn{1}{c|}{ Result } \\
\hline 1. & $\begin{array}{l}\text { Construction } \\
\text { control }\end{array}$ & $\begin{array}{l}\text { Ensuring the safety and reliability of structures; timely reaction in case of } \\
\text { a critical value (limiting condition) }\end{array}$ \\
\hline 2. & $\begin{array}{l}\text { Financial } \\
\text { management }\end{array}$ & $\begin{array}{l}\text { Using the bearing capacity latent reserves of the structural components; } \\
\text { reduction of materials consumption; positive economic effect }\end{array}$ \\
\hline 3. & $\begin{array}{l}\text { Scientific } \\
\text { organization } \\
\text { of labor } \\
\text { (SOL) }\end{array}$ & $\begin{array}{l}\text { Accumulation and systematization of knowledge about the actual behavior } \\
\text { of a material structure under load, taking into account the building loading } \\
\text { steps; updating the legal framework for the unique objects construction; } \\
\text { drawing up recommendations for the design and construction of unique } \\
\text { objects grouped by similarity (representative objects) }\end{array}$ \\
\hline
\end{tabular}

\section{Materials and methods}

In the considered object, full-bodied-reinforced concrete end-bearing piles 110.30-11u with square section 300x300 mm (section 1) and 100.40-11u size 400x400 mm (section 6) are applied. The procedure for sequential installation of TZB stress monitoring sensor in the pile body (depending on load) is shown in Table. 5.

Table 5. Procedure of sequential installation of TZB stress monitoring sensor in the pile body (depending on load).

\begin{tabular}{|c|c|c|}
\hline No. & Operations & $\begin{array}{l}\text { Photos from the scientific and technical support } \\
\text { facility }\end{array}$ \\
\hline 1. & $\begin{array}{l}\text { A hole of } 80 \mathrm{~mm} \text { diameter and } \\
400 \mathrm{~mm} \text { depth is drilled in the pile } \\
\text { surface using a core barrel (hole } \\
\text { size varies depending on the strain } \\
\text { gauge size) }\end{array}$ & \\
\hline 2. & $\begin{array}{l}\text { A tensometer is installed through } \\
\text { the bottom of the hole levelled by } \\
\text { special mixture }\end{array}$ & \\
\hline
\end{tabular}




\begin{tabular}{|c|c|c|}
\hline No. & Operations & $\begin{array}{l}\text { Photos from the scientific and technical support } \\
\text { facility }\end{array}$ \\
\hline 3. & $\begin{array}{l}\text { A repair mixture having strength in } \\
\text { a design time not less than } 100 \% \\
\text { of the concrete pile design class } \\
\text { (400x400mm - B30; 300x300mm - } \\
\text { B40.) is used for the hole } \\
\text { concreting. The tensometer } \\
\text { vertical position is visually } \\
\text { controlled during concreting. To } \\
\text { prevent damage to the power } \\
\text { supply wire, it is placed in a metal } \\
\text { sleeve. }\end{array}$ & 8. \\
\hline
\end{tabular}

Before carrying out tests on a construction site, a number of preparatory operations should be carried out. To convert units of stress arising under the influence of the design loads in the concrete body to the units of mass, calibration dependence is determined by testing the concrete test samples with installed tensometer.

Sample piles of $600 \mathrm{~mm}$ are used as control samples (Fig. 1, a)) for the tensometer installation. Specially manufactured samples with dimensions 300x300x300mm are used as control samples for the tensometer installation.

The sensor concreting is performed during the pylon (wall) structure concreting with a tensometer installed using identical concrete mix. This provides the control sample hardening will eb the same as hardening of the whole structure.
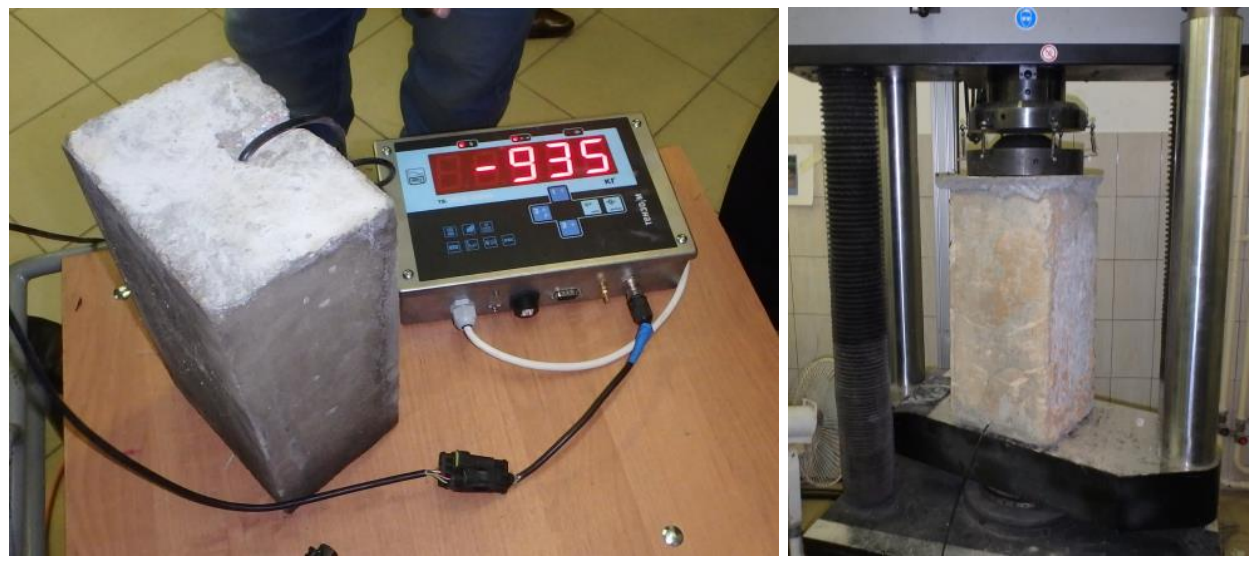

Fig. 1. A) Preparation of control sample test. B) Test of control samples using a hydraulic press.

Control samples tests are carried out using a hydraulic press (Fig. 1, b)). The readings obtained on the weighing transducer are considered indirect characteristic, and values of load $(\mathrm{kN})$ on a test press shall be direct characteristic

\section{Results and Discussion}

The load on control samples is exerted step-by-step. The values of direct and indirect characteristics are fixed after regular time periods. Based on these data, the calibration dependence is determined (Fig. 3) allowing the load ( $\mathrm{kN}$ ) of stresses occurring in the concrete body to be correlated. 


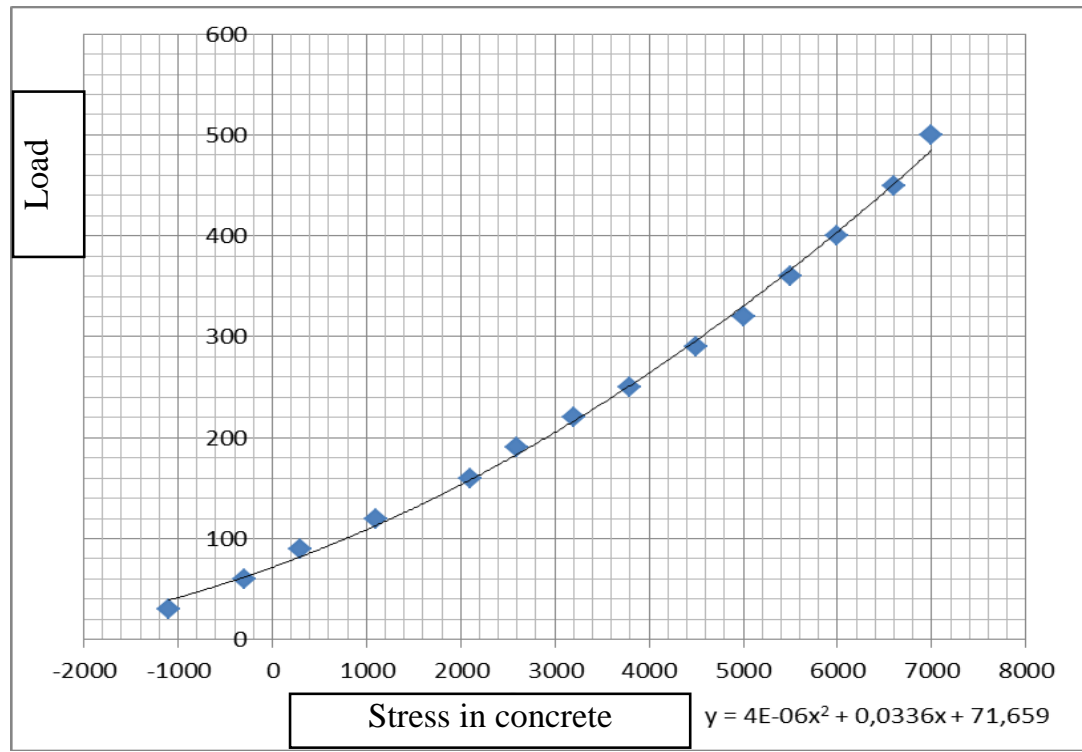

Fig. 3. The calibration dependence built based on the results of the control samples testing.

Table 6. Stages of measuring equipment readings obtaining and post-processing of the results of scientific and technical support of the construction and design of a unique facility.

\begin{tabular}{|l|l|}
\hline No. & $\begin{array}{l}\text { Stages of measuring equipment readings obtaining and post-processing of the results of } \\
\text { scientific and technical support of the construction and design of a unique facility }\end{array}$ \\
\hline & $\begin{array}{l}\text { obtaining readings and calculation using a calibration dependence at following stages of building } \\
\text { carcass loading }\end{array}$ \\
\hline 1. & - Initial measurement (after hardening) \\
\hline 2. & - Measurements after concreting the foundation plate \\
\hline 3. & - Measurements after the underground part construction \\
\hline 4. & - Measurements after construction of 50\% of reinforced concrete aboveground structures \\
\hline 5. & - Measurements after construction of 100\% of reinforced concrete aboveground structures \\
\hline 6. & $\begin{array}{l}\text {-Measurements after construction of interior walls and partitions, facades (after completion of } \\
\text { construction works on the examined sections) }\end{array}$ \\
\hline 7. & Analytical studies of the stress tensor in accordance with the design (calculated) data \\
\hline 8. & $\begin{array}{l}\text { Formation of conclusions and recommendations for further safe and reliable operation of constructed } \\
\text { structures, including making recommendations to reduce the consumption of materials in the } \\
\text { construction of structures of similar objects }\end{array}$ \\
\hline
\end{tabular}

Table 7. Description of the equipment used. Concrete embedded tensometer (TZB 100; TZB-200).

\begin{tabular}{|l|l|c|}
\hline \multicolumn{1}{|c|}{ No. } & \multicolumn{1}{|c|}{ Characteristics of the equipment used } & Value \\
\hline 1. & Measuring tensometer base $($ reduced length, $\mathrm{mm})$. & $100 ; 200$ \\
\hline 2. & Range of measured stress, $\mathrm{kg} / \mathrm{cm}^{2}$ & 300 \\
\hline 3. & Tensometer sensitivity $(\mathrm{mV} / \mathrm{V}) /\left(\mathrm{kg} / \mathrm{cm}^{2}\right)$ & 0,032 \\
\hline 4. & Tensiometer accuracy, $\%$ & $-2+$ \\
\hline 5. & Operating temperatures, ${ }^{\circ} \mathrm{C}$ & $-30 \ldots .+60$ \\
\hline 6. & Overload, \% Of the NPI & 50 \\
\hline 7. & Input electrical resistance, Ohm & 355.5 \\
\hline 8. & Output electric resistance, Ohm & 350.2 \\
\hline 9. & DC supply voltage, not more than, $\mathrm{V}$ & 12.0 \\
\hline 10. & Power consumption, not more than, VA & 0.4 \\
\hline 11. & Insulation resistance, MOhm, not less & 1000 \\
\hline 12. & Protection class according to GOST 14254 (IEC 529-89) & IP65 \\
\hline
\end{tabular}




\section{Conclusion}

To improve the quality of the construction supervision in the unique facilities construction, a set of measures of scientific and technical support described in this article can be applied. The strain studies described were performed within the framework of this support. Despite the fact that the importance and relevance of this kind of scientific research for the construction of unique objects is obvious, the modern legislation does not clearly regulate the contents and scope of scientific research during the scientific and technical support of construction and design (STSC). Timely monitoring of the state of the unique facilities considers interests of both the end user receiving the output quality finished building product and the initial investor, significantly reducing material consumption for the construction. The design companies obtain a very important control over the actual state of the structure during construction and will be able to response to possible emergency situations caused by design errors, legal framework imperfection in terms of design calculations of unique facilities construction and other destructive factors.

\section{References}

1. Russian Federation Standard SP 20.13330.2011

2. http://www.tenso-m.ru/

3. RF Code of 29.12.2004 N 190-FZ

4. Russian Federation Standard SP 13-102-2003

5. Russian Federation Standard GOST 31937-2011

6. Russian Federation Standard GOST 27751-2014

7. Russian Federation Standard SP 63.13330.2012

8. Russian Federation Standard SP 20.13330.2011

9. Russian Federation Standard TSN 50-304-2001

10. Russian Federation Standard SP 50-101-2004

11. Russian Federation Standard SP 45.13330.2012 (SNiP 3.02.01-87)

12. Russian Federation Standard SP 24.13330.2011

13. D. Topchiy, A. Shatrova, A. Yurgaytis, MATEC Web of Conferences 193 (2018)

14. D. Topchiy, E. Kochurina, MATEC Web of Conferences 193 (2018)

15. D. Topchiy, A. Tokarskiy, MATEC Web of Conferences 193, 04029 (2018)

16. D.V. Topchiy, A.I Shatrova, International Journal of Mechanical Engineering and Technology (2018)

17. D. Topchiy, A. Tokarskiy, IOP Conference Series: Materials Science and Engineering (2018)

18. I.L. Abramov, A.A. Lapidus, E3S Web of Conferences 33 (2018)

19. I. Abramov, E3S Web of Conferences, HRC 201733 (2018)

20. A. Lapidus, I. Abramov, MATEC Web of Conferences 193 (2018) 